\title{
A South African study on antecedents of intention to quit amongst employees in bed and breakfast establishments in the Free State province
}

\begin{tabular}{|c|c|}
\hline \multicolumn{2}{|c|}{$\begin{array}{l}\text { Authors: } \\
\text { Lebohang Monyaki }^{1} \text { (D) } \\
\text { Crispen Chipunza }^{1} \text { (D) } \\
\text { Nhamo Mashavira }^{2} \text { (D) }\end{array}$} \\
\hline \multicolumn{2}{|c|}{$\begin{array}{l}\text { Affiliations: } \\
\text { }{ }^{1} \text { Department of Business } \\
\text { Management, Faculty of } \\
\text { Management Sciences, } \\
\text { Central University of } \\
\text { Technology, Bloemfontein, } \\
\text { South Africa }\end{array}$} \\
\hline \multicolumn{2}{|c|}{$\begin{array}{l}{ }^{2} \text { Julius Nyerere School of } \\
\text { Social Sciences, Great } \\
\text { Zimbabwe University, } \\
\text { Masvingo, Zimbabwe }\end{array}$} \\
\hline \multicolumn{2}{|c|}{$\begin{array}{l}\text { Corresponding author: } \\
\text { Lebohang Monyaki, } \\
\text { lebohangmonyaki@gmail. } \\
\text { com }\end{array}$} \\
\hline \multicolumn{2}{|c|}{$\begin{array}{l}\text { Dates: } \\
\text { Received: } 20 \text { Aug. } 2021 \\
\text { Accepted: } 19 \text { Nov. } 2021 \\
\text { Published: } 28 \text { Feb. } 2022\end{array}$} \\
\hline \multicolumn{2}{|c|}{$\begin{array}{l}\text { How to cite this article: } \\
\text { Monyaki, L., Chipunza, C. \& } \\
\text { Mashavira, N., 2022, 'A South } \\
\text { African study on antecedents } \\
\text { of intention to quit amongst } \\
\text { employees in bed and } \\
\text { breakfast establishments in } \\
\text { the Free State province', } \\
\text { Southern African Journal } \\
\text { of Entrepreneurship } \\
\text { and Small Business } \\
\text { Management 14(1), a462. } \\
\text { https://doi.org/10.4102/ } \\
\text { sajesbm.v14i1.462 }\end{array}$} \\
\hline \multicolumn{2}{|c|}{$\begin{array}{l}\text { Copyright: } \\
\text { (C) 2022. The Authors. } \\
\text { Licensee: AOSIS. This wor } \\
\text { is licensed under the } \\
\text { Creative Commons } \\
\text { Attribution License. }\end{array}$} \\
\hline \multirow[b]{2}{*}{$\begin{array}{l}\text { Read online: } \\
\text { aris: }\end{array}$} & \\
\hline & $\begin{array}{l}\text { Scan this QR } \\
\text { code with your } \\
\text { smart phone or } \\
\text { mobile device } \\
\text { to read online. }\end{array}$ \\
\hline
\end{tabular}

Background: The continued growth in employment creation by small businesses in the hospitality sector necessitates research in organisational behaviour concepts such as turnover intentions that, for a long time, have been associated only with large organisations.

Aim: This study investigated the impact of selected individual and organisational factors on turnover intentions amongst employees in bed and breakfast (B\&B) establishments in a district in the Free State province of South Africa.

Setting: There is limited research within the South African context on antecedents of intention to quit amongst employees in B\&B establishments.

Methods: The study was purely quantitative. An ex post facto design was adopted. One hundred and forty four (144) employees were chosen using convenience sampling. Data were collected using a structured questionnaire and data analysis was done by way of structural equation modelling (SEM).

Results: Human resource practices, quality of work environment and organisational structure, all explained variance in intentions to quit. Human resource practices had a strong relationship with job satisfaction, and the quality of work environment was related to organisational commitment, while organisational structure explained employees' job stress.

Conclusion: The effectiveness of B\&B establishment owners' interventions to reduce intentions to quit amongst employees is dependent on the implementation of excellent human resource management (HRM) practices and creating a conducive work environment that promotes employees' long-term commitment to the business.

Keywords: bed and breakfast; hospitality industry; individual factors; intention to quit; organisational factors.

\section{Introduction}

Bed and breakfasts (B\&Bs) in South Africa are small accommodation establishments that strive to grow, whilst competing with large accommodation establishments (Hikido 2017). They are faced with several challenges such as low-paid employees who are not motivated to work because the work environment is stressful and demanding (Hlanyan \& Acheampong 2017). Small accommodation businesses, especially B\&Bs in South Africa, are also faced with the challenges of low income during off-seasons (Hsieh \& Lin 2010), as well as competition from large accommodation establishments (Van Schalkwyk et al. 2010). It is, therefore, highly likely that B\&B employees have high intentions to quit.

Intention to quit, also referred to as turnover intentions, that is, the thought of job searching and the inclination to consider a job offer and leave the current organisation (Ariyabuddhiphongs \& Kahn 2017; Cohen, Blake \& Goodman 2016) has ramifications in terms of increased recruitment costs and reduced production (Rizwan et al. 2014). Past studies (Cascio 1991; Johnson 1995) have estimated that the turnover of one employee can cost a business between $93 \%$ and $200 \%$ of that employee's salary depending on the individual employee's level of skill and responsibility. This is often because of the high costs associated directly with turnover, in areas such as recruitment, selection and training of new employees (Haque, Fernando \& Caputi 2017). When an employee leaves, an organisation is also bound to incur indirect costs in relation to organisational readjustment and maintaining team-based productivity (Tse, Huan \& Lam 2013). The impact of an employee's intention to quit is, therefore, a serious threat to organisations, not only in terms of productivity, but also concerning financial outcomes and organisational stability (Tse et al. 2013). 
It, therefore, goes without saying that appreciating the antecedents to employees' intention to quit and the identification of strategies to retain such employees cannot be over-emphasised. Researchers (Burakova et al. 2014; Halawi 2014; Treuren \& Frankish 2014) have pointed to a set of occupational, environmental and personal antecedents to employees' intention to quit. Job satisfaction and organisational commitment have been identified as the two common occupational antecedents to employees' intention to leave (Steil, Floriani \& Bello 2019), and with reference to environmental antecedents, these include but are not limited to the existence of employment alternatives (Heinen et al. 2013), the economic development level, social security policy, employment policy, labour demand and supply conditions (Li \& Lu 2014).

According to Steil et al. (2019), age, schooling, sex, marital status, professional experience and family or kinship responsibility are the six personal antecedents that have been researched the most. Whilst considerable research has been conducted on antecedents to employees' intention to leave, there is a dearth of research on the antecedents of employees' intention to quit amongst small businesses, especially B\&B establishments in the hospitality sector in South Africa. Whilst evidence is available on how organisation-related antecedents such as low compensation and those that are individual-related, for example, job satisfaction have been linked to intention to quit in large hospitality organisations in developing economies (Mat-Nor et al. 2017), the same cannot be said of such a relationship amongst B\&Bs found in either urban or rural contexts in developing economies.

With such paucity of research, the objective of this study was, therefore, to determine the influence of selected individual (job satisfaction, organisational commitment and job stress) and organisational factors (human resource practices, quality of work environment [QWE] and organisational structure) on intention to quit amongst employees in B\&Bs in a particular district in the Free State province of South Africa. The choice of these factors is premised on empirical evidence showing that they have been mostly linked to several behavioural outcomes in the hospitality sector (Chen, Ayoun \& Eyoun 2018; Grobelna, Sidorkiewicz \& Tokarz-Kocik 2016).

It has to be noted that employee turnover is costly to both parties in the employment relationship as the establishment has to invest more effort and time in acquiring, developing and retaining its employees (Grobler \& De Bruyn 2011) and to employees, as it directly interferes with their career development. High turnover amongst employees leads to direct financial costs, and also results in below average organisational performance manifested by low quality, lessened efficiency, decreases in morale and even service disruptions (Jang \& George 2012). The fact that employees have a high propensity to leave and look for alternative employment because of low salaries (Omar et al. 2012) gave impetus to the current inquiry. As such, the study sought to determine the impact of selected individual and organisational factors on intention to quit amongst employees in B \&Bs from a selected district in the Free State province.

\section{Literature review Job satisfaction versus intention to quit}

Job satisfaction is a general expression of workers' positive attitudes towards their jobs (Thomas 2015). It is pivotal in achieving positive organisational outcomes such as increased productivity (Kim et al. 2016), but can also lead to detrimental outcomes such as intention to quit (Poghosyan et al. 2017) if employees are not satisfied. Ibrar (2015) reported that job satisfaction does not only increase productivity but also decreases intention to quit amongst employees. This finding is corroborated by a study performed within the hospitality industry, which established that dissatisfied employees considered looking for alternative employment when they were not happy with working conditions, pay, relations with the supervisor and the job itself (Akgunduz \& Sanli 2017). Similarly, Santerosanchez et al. (2015) posited that $24 / 7$ working hours and high levels of job pressure in large established hotels are associated with job dissatisfaction, and ultimately intention to quit.

Contrastingly, other researchers found out that job satisfaction had no direct relationship with intention to quit but mediates the relationship between creativity and intention to quit (Zhen, Mansorzd \& Chong 2019). Notwithstanding this contradiction, there is also overwhelming evidence arguing that satisfaction levels differ by employee position, and, therefore, intentions to quit are not the same across all employees in any organisation ( $\mathrm{Lu}$ et al. 2016). Based on these findings, one can, therefore, conclude that job satisfaction has an impact on intention to quit amongst employees, even amongst B\&B employees. The above evidence leads to the following hypothesis:

H1: Job satisfaction has a significant positive effect on intention to quit.

\section{Organisational commitment versus intention to quit}

Organisational commitment is defined as:

[A] strong belief in and acceptance of the organisation's goals and values, a willingness to exert considerable effort on behalf of the organisation and a definite desire to maintain organisational membership. (Watson 2010, p.18)

The concept is conceived as associated with intention to quit in the sense that the two concepts are directly opposite to each other - one concerns the notion of being attached to the organisation and the other being detached from an organisation (Kim, Song \& Lee 2016).

Organisational commitment can assume three dimensions: normative commitment, affective commitment and continuance commitment (Meyer \& Allen 1997). Normative commitment 
reflects an employee's sense of duty to remain in employment, whilst affective commitment refers to the strength of an employee's identification with and involvement in an organisation (Porter et al. 1974). Continuance commitment deals with the cognitive attachment that exists between an employee and the organisation as the costs of quitting outweigh the benefits (Khan et al. 2018).

Employees who do not have much organisational commitment may have a high propensity to leave the organisation (Gatling, Kang \& Kim 2016). In contrast, employees with stronger organisational commitment are less likely to develop intentions to quit and leave the organisation (Wijnmaalen, Heyse \& Voordijk 2016). Committed employees who feel much attached to an organisation and are extremely dedicated are less likely to show intent to quit because of their high level of commitment and willingness to invest more into the organisation.

According to Kim, Im and Hwang (2015), service industry jobs are associated with high-stress levels, - a factor that works against employee organisational commitment. This is supported by Jung and Yoon (2016) who contended that the service industries' dependence on human resources makes employee commitment critical to maintain, failure of which has negative outcomes detrimental to the organisation such as intention to quit might ensue.

Related to this finding is a study which showed that whilst hospitality organisations can recruit talented and highly motivated employees, they seem to have difficulty in arousing their organisational commitment and, therefore, retain them (Chiang \& Liu 2017). Because retaining employees is determined by how committed employees are (Jang \& Kandampull 2018), hospitality organisations might need to ensure that there is commitment amongst their employees. As such, it is hypothesised that:

H2: Organisational commitment has a significant negative effect on intention to quit.

\section{Job stress versus intention to quit}

Job stress has been defined as 'the pattern of emotional states and psychological reactions occurring in response to inability to cope with stressors from within or outside an organization' (Ekienabor 2017:124). The reactions, which lead to high job stress, are likely to result in low morale and high turnover amongst employees (Bowness 2017). Lo and Lamm (2015) established that working in the hospitality industry can be stressful because the industry is highly labour-intensive and has increasingly harsh environmental demands imposed upon it.

Similarly, Namra and Tahira (2017) found that the nature of work within hotels and B\&Bs, for example, includes frequent deadlines, unexpected interactions with guests, long working hours, night and evening work, repetitive work, high emotional demands, low influence (control), shift work, extensive work space and problems with coordination of work. Consequently, such demands on employees lead to work-related stress.

Furthermore, evidence from a study by Mansor and Mohanna (2018) revealed that unpredictable and irregular working hours were stressful factors amongst hospitality organisations that led to increased intention to quit amongst employees. This was reaffirmed by Newnham (2017) who established that hospitality industry employees suffer from dissonance because they are required to display certain emotions all the time, which might not represent their actual feelings at any given time. The fact that these employees are continuously suppressing their actual emotions might lead to outcomes such as intentions to quit. The above review of literature led to the following hypothesis:

H3: Job stress has a significant positive effect on intention to quit.

\section{Human resource practices versus intention to quit}

Human resource practices refer to those organisational activities which are directed at managing the pool of human resources and ensuring that the resources are employed towards fulfilment of organisational goals (Russo, Mascia \& Morandi 2018). Some studies indicated that human resource activities linked to turnover intentions include the manner in which performance management is done (Nankervis \& Debrah 2015) and how employee compensation is managed (Khaleefa \& Al-Abdalaat 2017).

Aside from pay, promotional opportunities, effective and supportive leadership, satisfactory compensation and work-group cohesion have the potential to influence turnover (Qiu et al. 2015). Akgunduz, Gok and Alkan (2019) also concluded that good monetary incentives offered to employees often reduced employees intentions to quit. A related study by Santhanam et al. (2017) amongst hotel frontline employees established that selection, training and compensation practices had an influence on turnover intentions.

Interestingly, the study concluded that psychological contract breaches enhanced turnover intentions by employees, notwithstanding effective implementation of human resource management (HRM) practices. According to Lo and Lamm (2015) although employees in the hospitality industry are vulnerable in terms of poor working conditions and low wages, good compensation management practices might reduce their intentions to quit. However, Altarawmneh and Al-Kilan (2010) found out that despite the robust investment levels in HRM practices in Jordanian hotels, HRM practices themselves did not directly influence intentions to quit as employees' 
intentions to quit may depend on other factors. Based on the discussions above, it is hypothesised that:

H4: Human resource practices have a significant positive effect on intention to quit.

\section{Quality of work environment versus intention to quit}

Agbozo et al. (2017) confirmed that the QWE was a critical factor that influenced several outcomes, such as the level of satisfaction, intention to quit and motivation of the employees. The QWE is characterised by a good physical environment (e.g. in terms of heat or noise), a conducive psychological and social work environment (Agbozo et al. 2017).

Bednarska (2016) posited that the hospitality environment is one of the most complicated places to work in, with pressures on meeting expectations of customers and working long hours remaining foci pressure points for possible reactions by employees in the form of counterproductive work behaviours. Robinson et al. (2016) also acknowledged that shift work and the number of working hours put pressure on hospitality employees, significantly affecting their psychological, physical and emotional well-being, leading to turnover intentions.

A small survey of employees in New Zealand by Markey, Ravenswood and Webber (2015) found that a majority of employees intending to quit viewed the QWE as poor. The results also showed that employees were likely to quit if they were stressed, if they were not a parent, if they experienced reduced job satisfaction and did not receive adequate important information, although the impact of the aforesaid factors was greater in workplaces with a good QWE. In view of this, it is hypothesised that:

H5: The QWE has a significant positive effect on intention to quit.

\section{Organisational structure versus intention to quit}

Organisational structure is defined as the formal system of authority relationships and tasks that control and coordinate employee actions and behaviour to achieve organisational goals (Valentina \& Cvelbar 2018). Organisational structure is related to employee attitudes and behaviour in organisations (Valentina \& Cvelbar 2018). A study by Hamzat et al. (2020) amongst library and information science professionals in Nigeria's Osun State private universities revealed that the ownership structure of the organisation has a direct influence on the professionals turnover intention.

A related study by Lensen (2016) established that although a flat or non-hierarchical organisation (characterised by few lines of command and few layers) leads to greater expectations regarding job satisfaction and is considered more attractive, but it does not necessarily lead to lower turnover intentions. Regarding a functional structure, Cummings and Worley (2015) highlighted that the functional structure's emphasis on central power discourages growth, diminishes selfconfidence amongst employees and discourages them from becoming innovative and involved in business activities. Such a structure tends to work best in small-to-mediumsized enterprises like the B\&B establishments under study (Sinha 2017).

Another organisational structure, the customer-centric structure, which focuses on sub-units for the creation of solutions and satisfaction of key customers, is considered appropriate for hotels as it aims at meeting customer needs (Cummings \& Worley 2015). Previous researchers (PalaciosMarques, Guijarro \& Carrilero 2016) have attested that this approach can deliver significant benefits to an organisation. The benefits include: improved customer experience, reduced intentions to quit amongst employees, consistent engagement with customers and increased sales compared to other structural types like the functional structure. Based on the above discussion, the following hypothesis has been proffered:

H6: Organisational structure has a significant positive effect on intention to quit.

\section{Organisational and individual factors - More empirical evidence}

\section{Human resource practices and job satisfaction}

Human resource (HR) practices and job satisfaction have long been studied and are assumed to be closely associated (Ahmed, Zaman \& Khattak 2017; Cortini 2016; Kampkotter 2017), because it is believed that sound HR practices result in better levels of job satisfaction, which ultimately improves organisational performance. The aforesaid relationship has also been established within the hospitality sector in Portugal (Ferreira et al. 2017), Thailand (Ashton 2017) and Nigeria (Onyebu \& Omotayo 2017). It is evident from these studies that the use of specific HR practices in organisations is associated with greater levels of job satisfaction. This evidence led to the following hypothesis:

H7: HR practices have a significant positive effect on job satisfaction.

\section{Working environment versus organisational commitment}

Another area of interest is how the working environment affects organisational commitment. However, this area has not enjoyed much empirical attention in the literature (Holston-Okae 2017). Yet, workplace environmental factors are essential elements that determine the level of employees' commitment, their concentration and performance and the sustainability of a business (Funminiyi 2018). Funminiyi argued that employees are always content when they feel that their immediate environment - both physical sensations and emotional states - are in line with their obligations.

McCoy and Evans (2015) opined that the way employees connect with their organisation's immediate workplace environment, influences to a great extent their commitment, 
efficiency, innovativeness, collaboration with other employees, absenteeism and, ultimately, their retention. In view of this above, it can be hypothesised that:

H8: The QWE has a significant positive effect on organisational commitment.

\section{Organisational structure versus job stress}

The way an organisation is structured and how it is run can have a positive significant effect on job stress amongst employees. A study by Namra and Tahira (2017) found that job stress amongst hospitality employees was associated with changes in management and lack of participation in decision-making, which ultimately caused intention to quit because of employees' inability to be involved in the decisionmaking processes.

Despite the different context, a related study by Daoli and Mohsenvand (2017) found that employees who were subjected to a centralised organisational structure experienced job stress, which then caused higher absenteeism, lower productivity, workplace aggression and increased intentions to quit. Highly-centralised organisations often have low levels of flexibility which often affect employees' stress levels as workers have limited autonomy and control over their work (Daoli \& Mohsenvand 2017). Most small businesses usually follow a centralised structure (Vitez 2017); hence, one can conclude that high level of stress develops amongst B\&B employees which might lead to increased intention to quit. It is, therefore, hypothesised that:

H9: Organisational structure has a significant positive effect on job stress.

\section{Conceptual framework}

The conceptual framework as shown in Figure 1 depicts the researchers' understanding of how the variables in the current study connect with each other.

Figure 1 summarises the hypothesised relationships discussed in the literature review section. It is hypothesised that employees' intention to quit might be influenced by the two broad categories of factors - individual and organisational. No moderation influences were investigated. The framework further assumes that organisational factors have an impact on employees' individual factors.

\section{Research design}

A research design refers to the plan for the collection, measurement and analysis of data (Blumberg, Cooper \& Schindler 2014). The study used the correlational ex post facto design. A correlational design attempts to describe relationships, rather than explain them (Gravetter \& Forzano 2009). Although a correlational research does not imply causality, it allows for predictions to be made even though one may not have an idea why a relationship exists. The ex post facto is pre-experimental, implying that it does not meet the scientific standards of experimental designs, nor does it involve a control group (De Vos, Strydom, Fouché \& Delport 2011). The ex post facto design provides a means by which researchers may examine the degree to which an independent variable could affect the dependent variable(s) of interest.

\section{Research approach}

Kothari (2004) pointed out that there are two basic approaches to research - quantitative and qualitative. Researchers generally show a preference for either type of method, reflecting their research's philosophical point of view (Kothari 2004). Proponents of the positivistic school of thought commonly use quantitative methods, whereas qualitative methods tend to be chosen by researchers with an interpretivist attitude (Moon \& Moon 2004). The current study adopted the quantitative approach. Nykiel (2007) posited that quantitative research methods seek to establish facts, make predictions and test hypotheses that have already been stated using a deductive approach and establishing objective knowledge.

\section{Data collection}

The target population comprised of 231 B\&B employees from the selected district in the Free State province of South Africa. A sample of 144 respondents was subsequently surveyed using convenience sampling. Some authors (De Vos et al. 2011; Gray 2014) call convenience sampling haphazard, accidental, volunteer or availability sampling considering that participants are usually those most accessible.

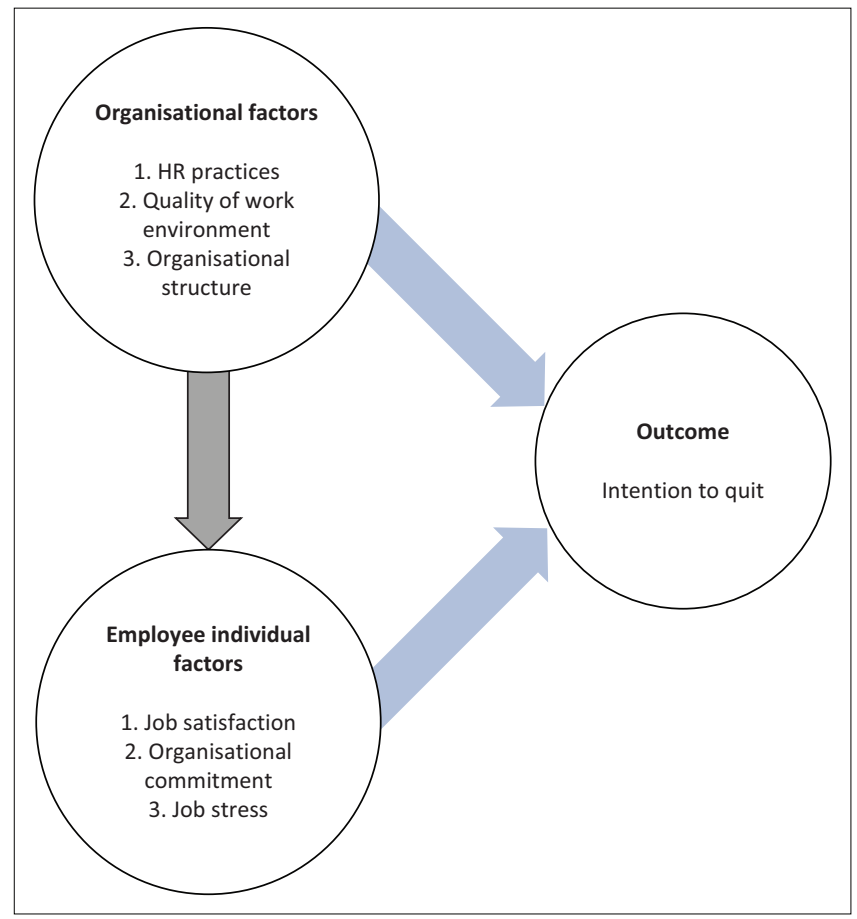

FIGURE 1: Conceptual framework of selected individual and organisational factors influencing intention to quit. 
Convenience sampling was considered most appropriate for obtaining a big sample that meets the minimum threshold of data required for structural equation modelling (SEM), given the limited amount of time to complete the research (Creswell 2012). Although subjects' opportunity to participate was not equal in convenience sampling, as the sample size increased, the statistical power of the convenience sample also increased (Etikan, Musa \& Alkassim 2016).

Data were collected using a structured questionnaire. The questionnaire had an introductory section which summarised research objectives and addressed ethical issues. Section A contained items on demographic information. Section B had three other sub-sections, namely, B1 and B2 and B3. B1 had specific sections on selected individual factors (job satisfaction, organisational commitment and job stress).

Respondents were required to indicate their level of agreement with given statements on a Likert scale, ranging from 1-Very Dissatisfied to 5-Very Satisfied and the other scale ranged 1-Strongly Disagree to 5-Strongly Agree for items measuring organisational commitment and job stress. Section C comprised of items measuring organisational factors (human resource practices, QWE, organisational structure). A five-point Likert scale ranging from 1-Strongly Disagree to 5-Strongly was used. Lastly, Section C had intention to quit items measured using a three-point Likert scale ranging from 1-Always to 2-Mostly and 3-Never.

\section{Data analysis}

Data were captured using the Statistical Package for Social Sciences (SPSS) version 25. Descriptive statistics were used to analyse the demographic characteristics of the sample. Thereafter, data were subjected to SEM using AMOS software techniques, to ascertain model fit.

\section{Ethical considerations}

Ethical approval to conduct the study was obtained from the Faculty Research and Innovation Committee (FRIC), Central University of Technology, Free State, reference number: FMSEC05/16. One of the researchers visited each business establishment in the province and requested employees to fill consent forms before their voluntary participation. The respondents were also informed of their right to withdraw from the study at any stage should they have felt any harm or threat. In order to maintain confidentiality, data were stored in an aggregate form.

\section{Results}

\section{Exploratory factor analysis}

An exploratory factor analysis (EFA) was performed to test the structure of the three main constructs, that is, organisational factors, individual factors and intention to quit. Such an analysis allowed for the empirical assessment of the validity of the scales used. The Kaiser-Meyer-Olkin (KMO) measure was calculated to ensure that the sample was adequate for factor analysis. Glen (2016) noted that the $\mathrm{KMO}$ test is a measure of how suited data are for factor analysis. The test measures sampling adequacy for each variable in the model and for the complete model (Glen 2016). The suitability of the data was supported because the KMO value (0.871) was superior to the threshold of 0.6 , and Bartlett's Test of Sphericity was significant $(p<0.001)$ (Pallant 2010). The KMO and Bartlett's Test of Sphericity confirmed that the data were suitable for factor analysis.

After ascertaining the suitability of the data for factor analysis, a principal component analysis, using the VARIMAX method was used to extract the factors with an Eigenvalue above 1. However, the analysis showed poor results. The items were not loading well into the factors. After presenting Eigen values as indicated in the scree plot above, the models (initial and refined) were examined as indicated in the next section.

\section{Model fit indices}

Before examining the model fit indices of the final measurement model, a univariate normality test was conducted to confirm whether the model could be estimated using the maximum likelihood method (Li \& Malik, 2018) The results are indicated below.

\section{Normality test}

A normality test is a statistical process used to determine if a sample or any group of data fits a standard normal distribution (Das \& Imon 2016). A normality test can be performed mathematically or graphically. Generally, the values for skewness and kurtosis between -2 and +2 are considered acceptable to prove normal univariate distribution (Cain, Zhang \& Yuan 2017). The results will not be affected by the non-normality distribution of data for all items used to measure the constructs, as most of their coefficients belong to the interval $[-2$ and +2$]$. Because the normality is supported, the maximum likelihood method was confidently used to assess the model fit of the initial model as indicated in Figure 2.

The model presented in Figure 2 is the measurement model before refinement. Its Chi-square $\left(X^{2}\right)$ was equal to 568798 , its $p$ value $<0.001$ (significant) and its degrees of freedom $(d f)=$ 249. Although this initial model suggests a significant Chisquare, there was a need to further examine model fit indices before concluding on the model. The fact that the Chi-square is very sensitive to the sample size is the reason most Chisquare of large samples are often significant (Hair et al. 2014).

A close diagnosis of the modification indices and the standardised residual covariance matrix retrieved from the IBM AMOS outputs suggested that some items should be deleted to improve the model fit indices. Items whose factor loadings were below 0.5 were also deleted.

Two inter-item correlations pertaining to the same construct were added to improve the model fit using the IBM 


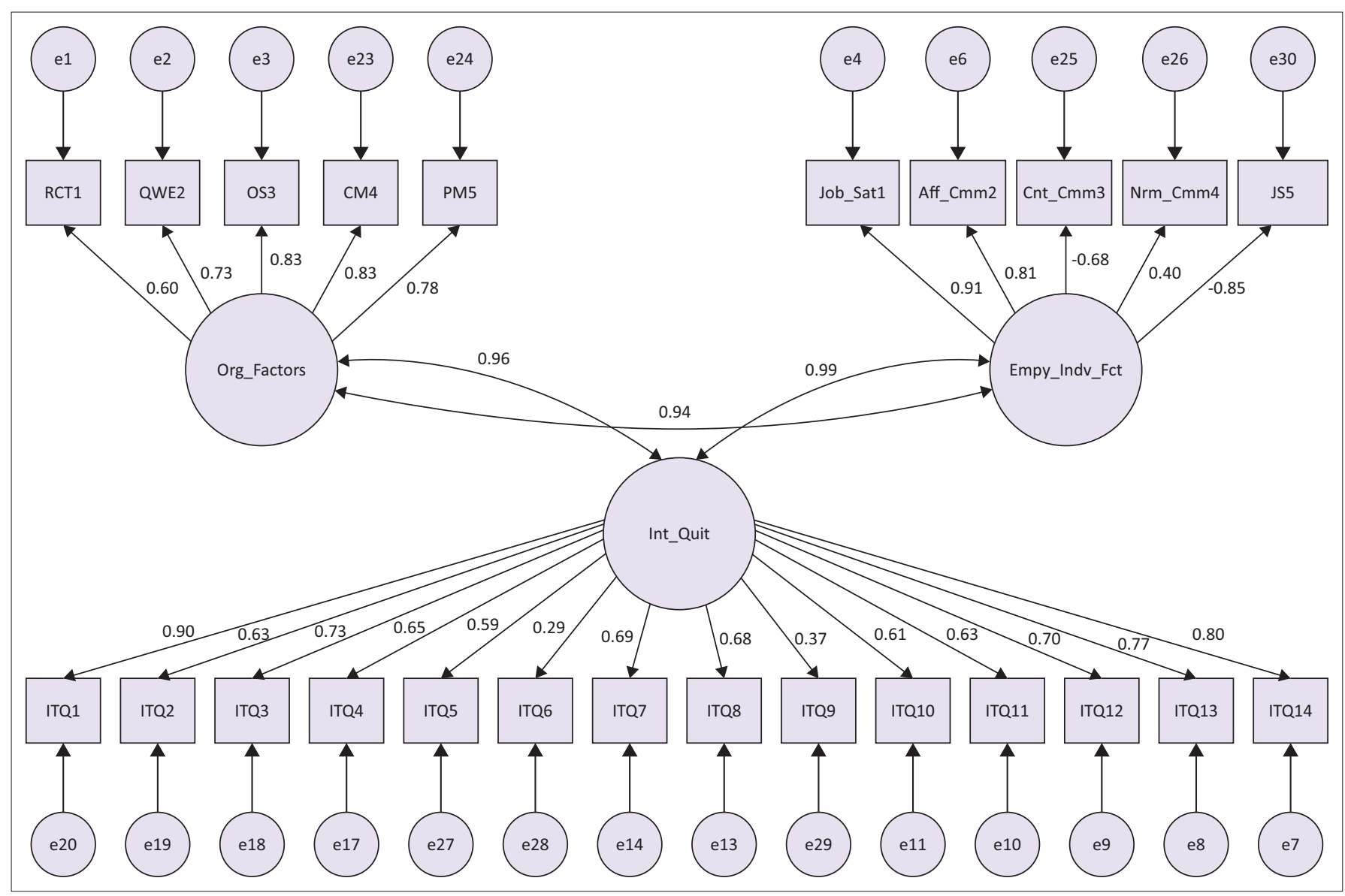

Source: (Survey Results, 2019)

Note: Aff_Cmm, affective commitment; CM, compensation management; Cnt_Cmm, continuance commitment; Empy_Indv_Fct, employee individual factors; Int_Quit, intention to quit; ITQ, intention to quit; Job_Sat, job satisfaction; JS, job satisfaction; Nrm_Comm, normative commitment; Org_Factors, organisational factors; OS, organisational structure; PM, performance management; QWE, quality of work environment; RCT, recruitment.

FIGURE 2: Unimproved (initial) measurement model.

AMOS function 'modification indices' (Hair et al. 2014). The addition of the inter-item correlations reduced the measurement error and improved the internal consistency of items (Ford, MacCallum \& Tait 1986), which in turn enhanced the model fit. Following the aforementioned amendments, a final measurement model was designed (see Figure 3).

The final measurement model as indicated in Figure 3 above indicates a significant and lower Chi-square $\left(\chi^{2}=242110 ; p=000 ; d f=130\right)$, which implies that this later version of the model is more improved than the initial measurement model as shown in Figure 2. The model fit indices of the final model are provided in Online Appendix 1, Table 1-A1. The table illustrates that the model fit indices of the final measurement model were better than the initial model, therefore, the final measurement model could be interpreted.

\section{Reliability analysis, convergent and discriminant validity assessment}

The final measurement model illustrated in Figure 4 was considered as the graphical evidence of convergent and discriminant validity. All the factor loadings were above 0.5, suggesting a convergent validity of all the items. The moderate level of correlations above 0.8 suggests a discriminant validity concern of all three latent variables. Further robust statistical evidence is provided in Online Appendix 1, Table 2-A1 to establish the validity of all the research instruments used in the study. The table indicates a good reliability for all the scales used in this study as Cronbach alphas and composite reliability coefficients were both above 0.7 (Vaske, Beaman \& Sponarski 2017). Online Appendix 1, Table 2-A1 also shows that the factor loadings of all constructs were above the recommended threshold of 0.5 (Hair et al. 2014). Similarly, the average variances extracted (AVEs) of all constructs were also above the required cut-off of 0.5 (Ahmad, Zulkurnain \& Khairushalimi 2016). In addition, the overall result indicates a good reliability of all the scales involved in this study (see Online Appendix 1) as Cronbach alphas and composite reliability coefficients were both above 0.7 (Bagozzi \& Yi 1988).

All the estimates on Online Appendix 1, Table 2-A1. statistically confirm that there was convergent validity of all the items in the final measurement model. This means that all the items selected were good measures of their respective constructs. The statistical evidence of discriminant validity was assessed and discussed using the matrix of correlations and AVE square root coefficients as indicated in Online 


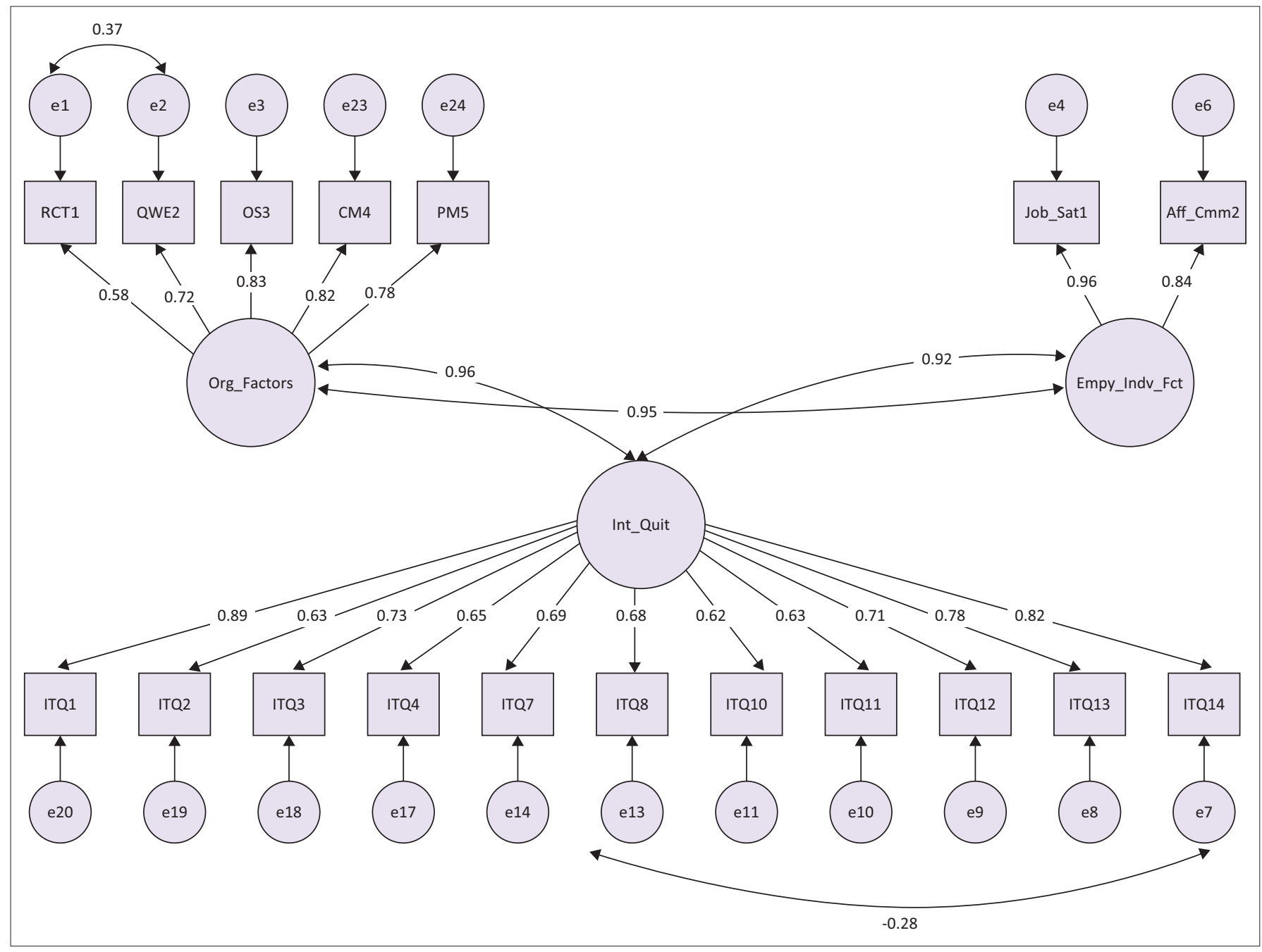

Source: (Survey Results, 2019)

Note: Aff_Cmm, affective commitment; CM, compensation management; Empy_Indv_Fct, employee individual factors; Int_Quit, intention to quit; ITQ, intention to quit; Job_Sat, job satisfaction; Org_Factors, organisational factors; OS, organisational structure; PM, performance management; QWE, quality of work environment; RCT, recruitment.

FIGURE 3: The final measurement model.

Appendix 1, Table 3-A1. Discriminant validity is assessed through a comparison between the square root of the AVE estimates and the highest inter-construct correlation of the specific construct (Malhotra, Nunan \& Birks 2017). The square root of the AVE is expected to be above all the interconstruct correlation values.

\section{Structural equation modelling}

The structural model was tested using the maximum likelihood performed with AMOS 25. The structural model for the study is presented in Figure 4.

The structural model $\left(X^{2}=242110 ; p=0.000 ; d f=130\right)$ displayed satisfactory fit indices: minimum discrepancy per degree of freedom $(\mathrm{CMIN} / \mathrm{DF})=1862$; Goodness of fit Index $(\mathrm{GFI})=$ 0.854; Adjusted Goodness of Fit Index (AGFI) = 0.808; TuckerLewis Index $(\mathrm{TLI})=0.938$; Comparative Fit Index $(\mathrm{CFI})=0.947$, Normed Fit Index $(\mathrm{NFI})=0.894$, Root Mean Square Error of Approximation $($ RMSEA $)=0.072$. It could be concluded that the structural model fitted the data satisfactorily. Therefore, the structural model was used with confidence to examine the research hypotheses of the study.

\section{Hypotheses testing}

The study tested hypotheses in relation to whether selected individual and organisational factors have an influence in determining intention to quit amongst $B \& B$ employees. Regression analysis was used to determine the impact of the independent variables of the study on the dependent variables. The results are presented in Online Appendix 1, Table 6-A1.

\section{Regression weights}

The model explains up to $92.2 \%$ of the intention to quit and $89.4 \%$ of the individual factors. The details of the impact of each independent variable are provided in Online Appendix 1, Table 4-A1. Regression weights as shown in Online Appendix 1, Table 4-A1. Showed that all of the employee individual factors did not have a significant effect on intention to quit $(\beta=0.495, p>0.05)$. This means that improving the employee individual factors does not translate into intention to quit. The regression results also showed that organisational factors had a positive and significant effect on intention to quit $(\beta=0.814, p<0.01$ ). 


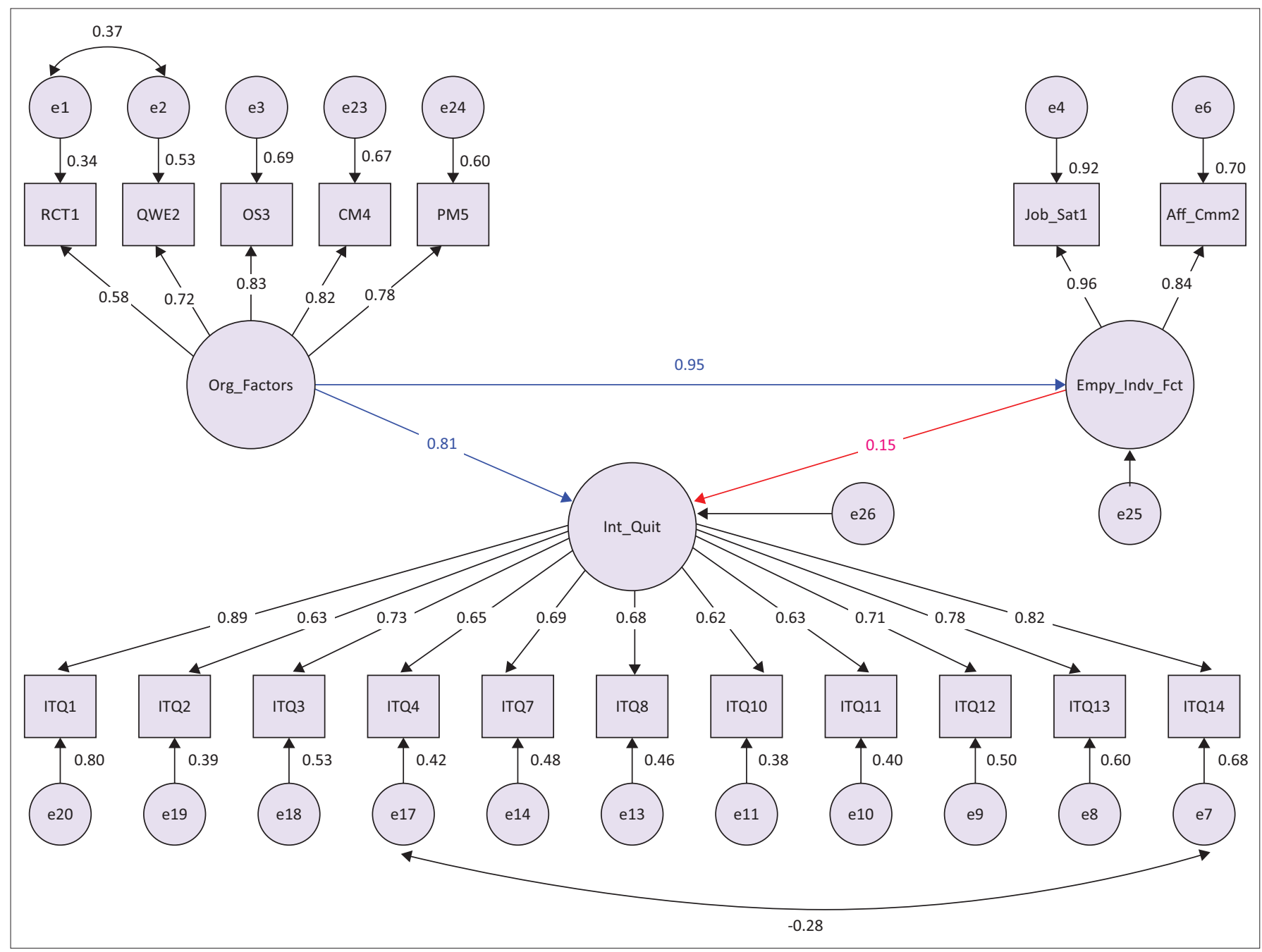

Source: (Survey Results, 2019)

Note: Aff_Cmm, affective commitment; CM, compensation management; Empy_Indv_Fct, employee individual factors; Int_Quit, intention to quit; ITQ, intention to quit; Job_Sat, job satisfaction; Org_Factors, organisational factors; OS, organisational structure; PM, performance management; QWE, quality of work environment; RCT, recruitment.

FIGURE 4: The structural model.

This means that when any of the organisational factors goes up by 1 standard deviation (SD), there are $99 \%$ of chances that intention to quit also goes up by 0.814 of its own SD. The specific hypotheses results relating to specific factors are presented below.

\section{Discussion of findings}

\section{Job satisfaction versus intention to quit}

Online Appendix 1, Table 4-A1 revealed that job satisfaction (one of the individual factors) did not have an influence on intention to quit. We, therefore, accept the null hypothesis and reject the alternative hypothesis (H1) which says, job satisfaction has a significant positive effect on intention to quit. Most studies that investigated the impact of job satisfaction on intention to quit have been conducted amongst large hospitality organisations, such as hotels.

For instance, past studies (Albattat, Som \& Helalat 2013; Sangaran \& Jeetesh 2015) found that intention to quit occurs when there is dissatisfaction in the job. These findings are contrary to those of the current study because given the high unemployment rate in South Africa (Wang 2019), employees could be left with but little choice. However, the current study's results corroborate those by Holston-Okae (2017), who found out that job satisfaction within the hospitality industry correlates inversely with employee intention to quit to a statistically significant degree.

\section{Organisational commitment versus intention to quit}

Results in Online Appendix 1, Table 4-A1 show that all aspects of another individual factor - organisational commitment (affective, continuance and normative) had no significant positive influence on intention to quit. We, therefore, accept the alternative hypothesis $\mathrm{H} 2$, which says that organisational commitment has a significant negative effect on intention to quit. This is contrary to a study conducted by Ghosh and Gurunathan (2015) that established organisational commitment as one of the major factors that influences intention to quit amongst employees in the hospitality industry. Although Johansson (2016) revealed that in most American small businesses, lack of organisational commitment is one of the factors that causes 
intention to quit amongst employees, the current study refutes such claims. Such discrepancies could only be accounted for by issues of context.

\section{Job stress versus intention to quit}

Results in Online Appendix 1, Table 4-A1 revealed that job stress (one of the individual factors) had no significant association with B\&B employees' intention to quit. This led us to accept the null hypothesis and reject the alternative hypothesis (H3) which says that job stress has a significant positive influence on intention to quit. These findings are contrary to a study by Hang-yue, Foley and Loi (2015), who found that job stress exerts a significant positive effect on intention to quit. The current study's results are also contrary to previous studies (Hwang et al. 2016; Namra \& Tahira 2017), which revealed that hospitality work can be stressful leading to increased intention to quit amongst employees.

\section{Human resource practices versus intention to quit}

This study established that selected human resources practices had a significant positive influence on intention to quit amongst B\&B employees. This led us to accept the alternative hypothesis (H4), which says that human resource practices have a significant positive effect on intention to quit. A study by Santhanam et al. (2015) showed that human resources practices such as compensation, performance management and recruitment can affect employee outcomes such as intention to quit. With others, satisfactory compensation was found to reduce intention to quit and led to employee retention (Pohler \& Schmidt 2015). Afsar, Shahjehan and Shah (2018) observed that employees who perceive their organisation to be in poor financial condition and do not receive their desired compensation may anticipate future layoffs and may pre-emptively leave. These factors help buttress the eminence of human resource practices in small businesses.

\section{Quality of work environment versus intention to quit}

Regarding the QWE and employees' intention to quit, a statistically significant positive effect was found between the two. Therefore, the alternative hypothesis (H5) which states that the QWE has a significant positive effect on intention to quit was accepted. These findings supported the conclusions previously reported by Robinson et al. (2016) that a dynamic and interactive environment may lead to higher job satisfaction of employees and, ultimately, employee retention, amongst other organisational benefits. Similarly, Kang, Busser and Choi (2018) noted that unfavourable perceptions of work environments lead to negative workplace outcomes, including turnover, whilst meaningful working environments deter intention to quit in a variety of job contexts.

\section{Organisational structure versus intention to quit}

Organisational structure was found to have had an impact on intention to quit. This led to the acceptance of the hypothesis (H6) which states that organisational structure has a significant positive effect on intention to quit. According to Katsikea, Theodosiou and Morgan (2016), organisations that focus on a team-based approach rather than the typical hierarchical structure are in a better position to retain their employees. Afsar et al. (2018) called such organisations high performance organisations, that is, organisations that try to bring out the best in individuals and create an exceptional capability to deliver high-end results.

Cummings and Worley (2015) stated that high performance organisations include organisations with divisional and process structures. A study by Katsikea et al. (2016) found that hospitality organisations that follow the divisional and process structures have reduced rates of intention to quit than those with a functional structure. Work in the hospitality sector, especially hotels and B\&Bs, follows the division structure approach, with say a frontline section, kitchen section and so on.

\section{Association between organisational and individual factors}

Online Appendix 1, Table 5-A1 also indicates that organisational factors had a positive and significant effect on employee individual factors $(\beta=0.946, p<0.05)$. This means that when any of the organisational factors goes up by 1 SD, there are $99 \%$ chances that corresponding hypothesised individual factors also go up by 0.946 of their own standard deviation. The specific hypotheses results with corresponding factors are presented below.

\section{HR practices versus job satisfaction}

Selected human resources practices (compensation management, performance management and recruitment) were found to be associated with job satisfaction. This led to the acceptance of the alternative hypothesis (H7) which states that HR practices have a significant positive effect on job satisfaction. Haider et al. (2015) maintained that total compensation planning can help improve job satisfaction and increase employee retention. Hospitality organisations, such as B\&Bs, might have to ensure that their compensation policies are satisfactory to employees.

In addition, one other HR practice, performance management, plays an important role in employee motivation and satisfaction (Ushus \& Johney 2015). According to Ushus and Johney (2015), when employees receive high quality appraisal experience, they will tend to feel satisfied and motivated about their job and tasks given to them. Likewise, recruitment has been found to play a positive role in ensuring worker performance and positive job satisfaction outcomes (Agoi 2016). It is often claimed that recruitment of workers occurs not just to replace departing employees or add to a workforce but, rather, it aims to put in place workers who 
can perform at a high level and demonstrate commitment, thereby leading to high levels of job satisfaction (Ballantyne 2014).

\section{Quality of work environment versus organisational commitment}

Quality of work environment was found to have an influence on organisational commitment amongst B\&B employees. The alternative hypothesis (H8) which says that the QWE has a significant positive effect on organisational commitment was accepted. The results are in tandem with Hanaysha (2016) who maintained that internal work events and elements of the work environment shape employees' commitment to an organisation. The present findings also support the empirical evidence that work environment has the most significant influence on organisational commitment amongst hospitality employees (Ebrahim 2014). This is corroborated by Lee, Back and Chan (2015) who reported that in the hospitality industry, employees' poor commitment to an organisation is closely linked to excess work, pressure of work and difficult customers which are all aspects of the work environment. It is, therefore, evident that the QWE can lead to organisational commitment amongst B\&B employees.

\section{Organisational structure versus job stress}

The present study showed that organisational structure has a significant positive effect on job stress. The alternative hypothesis (H9) was proved true. These results support the conclusions by Kanten, Kanten and Gurlek (2015) that employees in high performance organisations (those that follow the divisional or decentralised structures) possess greater levels of organisational trust than employees in traditional hierarchical organisations, thereby leading to reduced stress levels.

Conversely, Cummings and Worley (2015) acknowledged that goals that traditional organisations (those following formalised and functional structures) tend to focus on are primarily how well the company is doing (business goals), whereas high performance organisations' goals tend to be more related to customer satisfaction, improving employee skills, as well as adapting to change within the workplace. The former structure is likely to result in increased stress, whilst the latter is likely to result in reduced stress and intention to quit amongst employees. Considering that B\&B workspaces are more divisional and decentralised in structure, the current results are not surprising.

\section{Conclusions and recommendations}

This study investigated the impact of selected individual and organisational factors on intention to quit amongst employees in one of the districts in South Africa. Specifically, the study measured job satisfaction, organisational commitment and job stress (individual factors), as well as HR practices, QWE and organisational structure (organisational factors) and their impact on intention to quit. The results supported that organisational factors have a positive significant effect on intention to quit amongst B\&B employees.

In terms of individual factors, the results showed that there were no significant relationships between the selected factors, namely, job satisfaction, organisational commitment and job stress and intention to quit amongst $\mathrm{B} \& \mathrm{~B}$ employees. These results were contradictory to the research hypotheses and literature reviewed which found that the selected individual factors and intention to quit were significantly correlated.

It is, therefore, recommended that $B \& B$ owners/managers put more focus on improving organisational factors, so as to allow effective implementation of retention strategies. For example, continuously creating and maintaining a conducive work environment within $\mathrm{B} \& \mathrm{~B}$ establishments might result not only in minimising intentions to quit but also improved business reputation and performance.

Also, effective HR practices, such as satisfactory compensation, could also play an important role in assisting managers retain their skilled employees as it is evident that satisfactory compensation packages and benefits influence employee motivation, loyalty and result in low levels of intentions to quit amongst employees (Khaleefa \& AlAbdalaat 2017). It is also recommended that owners or managers of B\&Bs conduct needs-analysis within their organisations to identify areas for improvement. This could prevent high rates of intention to quit within these establishments.

Future studies might consider conducting similar research in other districts or provinces in South Africa with larger sample sizes for more robust findings. Further studies could also consider demographic factors, such as age, which are likely to influence intention to quit amongst employees in $B \& B$ establishments. It could also be interesting to contrast how intentions to quit differ amongst employees in $B \& B$ establishments against those in large companies.

\section{Limitations of the study}

The study was based on B\&B establishments in a selected district in the Free State province of South Africa. This means that the results might have limited applicability to other similar institutions. The other limitation lies in the fact that there was a discriminant validity concern in the final measurement model for all constructs (organisational factors, intention to quit and individual factors). It is, however, encouraging to note that despite the discriminant validity concern, convergent validity was met, therefore, the results of the present study might be a basis upon which similar studies can be established.

\section{Acknowledgements}

The authors acknowledge the Central University of Technology, Free State, and the National Research 
Foundation (NRF) for providing the grant for the study, as well as all B\&B establishments that voluntarily participated in the study.

\section{Competing interests}

The authors declare that they have no financial or personal relationships that may have inappropriately influenced them in writing this article.

\section{Authors' contributions}

L.M. conceptualised the study and collected the data and was responsible for the first draft writing review, whilst C.C. and N.M focused on methodology, analysis of data, writing of results and language editing.

\section{Funding information}

The Central University of Technology, Free State, and the NRF provided funding for this research.

\section{Data availability}

Data can be easily accessed from authors upon request.

\section{Disclaimer}

The views and opinions expressed in this article are those of the authors and do not necessarily reflect the official policy or position of any affiliated agency of the authors, and the publisher.

\section{References}

Afsar, B., Shahjehan, A. \& Shah, S.I., 2018, 'Frontline employees' high-performance work practices, trust in supervisor, job embeddedness and turnover intentions in hospitality industry', International Journal of Contemporary Hospitality Management 30(3), 1436-1452. https://doi.org/10.1108/IJCHM-11-20160633

Agbozo, G.K., Owusu, S.I., Hhoedoafia, M.A. \& Atakorah, Y.B., 2017, 'The effect of work environment on job satisfaction: Evidence from the banking sector in Ghana', environment on job satisfaction: Evidence from the banking sector in Ghana',
Journal of Human Resource Management 5(1), 12-18. https://doi.org/10.11648/j. Journal of Human

Agoi, I.F., 2016, 'Influence of human resource management practices on employee satisfaction in public sugar manufacturing firms in Kenya', PhD thesis, Jomo Kenyatta University of Agriculture and Technology, Nairobi.

Ahmad, S., Zulkurnain, N. \& Khairushalimi, F., 2016, 'Assessing the validity and reliability of a measurement model in structural equation modeling (SEM)', British Journal of Mathematics and Computer Sciences 15(3), 1-8. https://doi. org/10.9734/BJMCS/2016/25183

Ahmed, A., Zaman, Y. \& Khattak, A., 2017, 'Impact of HR practices on employees' job satisfaction: A case study from fertilizer industry in Pakistan', Management Science Letters 7(2017), 225-232. http://doi.org/10.5267/j.msl.2017.2.004

Akgunduz, Y., Gok, A. \& Alkan C., 2019, 'Perceived organizational support, employee creativity and proactive personality: The mediating role effect of meaning of work', Journal of Hospitality and Tourism Management 34, 105-114. https://doi. org/10.1016/j.jhtm.2018.01.004

Akgunduz, Y., \& Sanli, S.C., 2017, 'The effect of employee advocacy and perceived organizational support on job embeddedness and turnover intention in hotels', Journal of Hospitality and Tourism Management 31, 118-125. http://doi. org/10.1016/j.jhtm.2016.12.002

Albattat, A.R., Som, A.M. \& Helalat, A.S., 2013, 'Overcoming Staff Turnover in the Hospitality Industry using Mobley's Model', International Journal of Learning \& Development 3(6), 64-66.

Altarawmneh, I. \& al-Kilani, M.H., 2010, 'Human resource management and turnover intentions in the Jordanian Hotel Sector', Research and Practice in Human Resource Management 18(1), 46-59.

Ariyabuddhiphongs, V. \& Kahn, S.I., 2017, 'Transformational leadership and turnover intention: The mediating effects of trust and job performance on café employees in Thailand', Journal of Human Resources in Hospitality and Tourism 16(2) 215-233. https://doi.org/10.1080/15332845.2016.1202730
Ashton, A.S., 2017, 'How human resources best practice influence employee satisfaction and job retention in the Thai hotel industry', Journal of Human Resources in Hospitality and Tourism 17(2), 175-199. https://doi.org/10.1080/15 Resources in Hospitality a
332845.2017.1340759

Bagozzi, R.P. \& Yi, Y., 1988, 'On the evaluation of structural equation models', Journal of the Academy of Marketing Science 16(1), 74-94. https://doi.org/10.1007/ BF02723327

Ballantyne, I., 2014, Recruiting and selecting staff in organizations. Human resource management, Oxford University Press, Oxford.

Bednarska, M., 2016, 'Contemporary person-environment fit as a predictor of job pursuit intentions in the service industry', Contemporary Economics 10(1), 27-38. https://doi.org/10.5709/ce.1897-9254.196

Blumberg, B., Cooper, D.R. \& Schindler, P.S., 2014, Business research methods, McGraw-Hill Education, London.

Bowness, A., 2017, Life as we know it: The impact of stress in the workplace for your employees, viewed 17 March 2020, from https://www.saba.com/blog/life-as-weknow-it-the-impact-of-stress-in-the-workplace-for-your-employees.

Burakova, M., Ducourneau, J., Gana, K. \& Dany, L., 2014, 'Pronostic de l'intention de départ chez les sapeurs-pompiers volontaires en France [Predicting intention to leave among volunteer fire-fighters in France]', Psychologie Francaise 59(4), 273-300. https://doi.org/10.1016/j.psfr.2013.12.002

Cain, M.K., Zhang, Z. \& Yaun, K.H., 2017, 'Univariate and multivariate skewness and kurtosis for measuring non-normality: Prevalence, influence and estimation', Behavior Research Methods 49(5), 1716-1735. http://doi.org/10.3758/s13428 016-0814-1

Cascio, W.F., 1991, Costing human resources, South-Western Educational Publishing, Boston, MA.

Chen, H., Ayoun, B. \& Eyoun, K., 2018, 'Work-family conflict and turnover intentions: A study comparing china and us hotel employees', Journal of Human Resources in Hospitality and Tourism 17(2), 247-269. https://doi.org/10.1080/15332845.2017. 1406272

Chiang, C.F. \& Liu, B.Z., 2017, 'Examining job stress and burnout of hotel room attendants: Internal marketing and organizational commitment as moderators', Journal of Human Resources in Hospitality and Tourism 16(4), 367-383. https:// doi.org/10.1080/15332845.2017.1266869

Cohen, G., Blake, R.S. \& Goodman, D., 2016, 'Does turnover intention matter? Evaluating the usefulness of turnover intention rate as a predictor of actual turnover rate', Review of Public Personnel Administration 36(3), 240-263. https:// doi.org/10.1177/0734371X15581850

Cortini, M., 2016, 'Workplace identity as a mediator in the relationship between learning climate and job satisfaction during apprenticeship: Suggestions for HR practitioners', Journal of Workplace Learning 28(2), 54-65. http://doi. org/10.1108/JWL-12-2015-0093

Creswell, J.W., 2012, Qualitative inquiry \& research design: Choosing among five approaches, 4th edn., Sage, Thousand Oaks, CA.

Cummings, T.G. \& Worley, C.G., 2015, Organisation development and change, Cengage Learning, Mason, CA

Daoli, A.C. \& Mohsenvand, A., 2017, 'The relationship between organizational structure and employee job stress', Arabian Journal of Business and Management Review 6(9), 27-30.

Das, K.R. \& Imon, R., 2016, 'A brief review of tests for normality', American Journal of Theoretical and Applied Statistics 5(1), 5-12. https://doi.org/10.11648/j. ajtas. 20160501.12

De Vos, A.S., Strydom, H., Fouché, C.B. \& Delport, C.S.L., 2011, Research at grassroots: For the social sciences and human services professions, 4th edn., Van Schaik Publishers, Cape Town.

Ebrahim, S., 2014, 'The causes of high staff turnover within selected hotels in Cape Town, South Africa', Masters' thesis, Cape Peninsula University of Technology, Cape Town.

Ekienabor, E.E., 2016, 'Impact of job stress on employees' productivity and commitment', International Journal for Research in Business 2(5), 124-134.

Etikan. I., Musa, S.A. \& Alkassim, R.S., 2016, 'Comparison of convenience sampling and purposive sampling', American Journal of Theoretical and Applied Statistics 59(1), 1-4. https://doi.org/10.11648/j.ajtas.20160501.11

Ferreira, A.I., Martinez, I.F., Lamelas, J.P. \& Rodrigues, R.I., 2017, 'Mediation of embeddedness and satisfaction in the relationship between task characteristics and turnover: A multilevel study in Portuguese hotels', International Journal of Contemporary Hospitality Management 29(1), 248-267. htpp://doi.org/10.1108/ IJCHM-03-2015-0126

Ford, J.K., Mzccallum, R.C. \& Tait, M., 1986, 'The application of exploratory factor analysis in applied psychology: A critical review and analysis', Personnel Psychology 39(2), 291-314. https://doi.org/10.1111/j.1744-6570.1986.tb00583.x

Funminiyi, A.K., 2018, 'Impact of workplace environmental factors on employee commitment: Evidence from North East Nigeria', International Journal of Scientific Research and Management 6(7), 575-585. https://doi.org/10.18535/ijsrm/v6i7. em08

Gatling, A., Kang, H.J. \& Kim, S., 2016, 'The effect of authentic leadership and organizational commitment on turnover intention', Leadership and Organizational Development Journal 37(2), 181-199. https://doi.org/10.1108/LODJ-05-2014-0090

Ghosh, D. \& Gurunathan, L., 2015, 'Do commitment-based human resource practices influence job embeddedness and intention to quit?' Indian Institute of Management Bangalore Management Review 27(4), 240-251. http://doi. org/10.1016/j.iimb.2015.09.003 
Glen, S., 2016, Convergent validity and discriminant validity: Definition, examples, viewed 12 August 2018, from https://www.statisticshowto.datasciencecentral. com/convergent-validity/

Gravetter, F.J. \& Forzano, L.A. B., 2009, Research methods for the behavioral sciences, Wadsworth Cenage Learning, Belmont, CA.

Gray, D.E., 2014, Doing research in the real world, 3rd edn., Sage, Los Angeles, CA.

Grobelna, A., Sidorkiewicz, M. \& Toarz-kocik, A., 2016, 'Job satisfaction among hotel employees: Analyzing selected antecedents and job outcomes. A case study from Poland', Argumenta Oeconomica 2(37), 281-310. htpp://doi.org/10.15611/ aoe.2016.2.11

Grobler, P.A. \& De Bruyn, A.J., 2011, 'Flexible work practices (FWP)-an effective instrument in the retention of talent: A survey of selected JSE-listed companies', South African Journal of Business Management 42(4), 63-78. https://doi. org/10.4102/sajbm.v42i4.506

Haider, M., Aamir, A., Hamid, A.A. \& Hashim, M., 2015, 'A literature analysis on the importance of non-financial rewards for employees' job satisfaction', Abasyn Journal of Social Sciences 8(2), 341-354.

Hair, J.F., Black, W.C., Babin, B.J. \& Anderson, R.E., 2014, Multivariate data analysis Pearson New International Edition, Pearson, Harlow.

Halawi, A. H., 2014, 'Stimuli and effect of the intention to leave the organisation' European Scientific Journal 1, 184-198. https://doi.org/10.19044/esj.2014. v10n $10 \mathrm{p} \% 25 \mathrm{p}$

Hamzat, S.A., Abata-Ebire, B.D., Ogunjinmi, T.T. \& Babarinde, O.M., 2020, 'Influence of ownership structure and leadership styles on turnover intention of LIS professionals: Empirical evidence from private universities in Osun State Nigeria', Library Philosophy and Practice (e-journal) 4486, 1-16.

Hanaysha, J., 2016, 'examining the effects of employee empowerment, teamwork, and employee training on organizational commitment', Procedia-Social and BehaviouralSciences 229, 298-306. https://doi.org/10.1016/j.sbspro.2016.07.140

Hang-yue, N., Foley, R. \& Loi, S., 2015, 'Work role stressors and turnover intentions: A study of professional clergy in Hong Kong', The International Journal of Human Resources Management 16(1), 2133-2146. https://doi.org/10.1080/ 09585190500315141

Haque, A., Fernando, M. \& Caputi, P., 2017, 'The relationship between responsible leadership and organisational commitment and the mediating effect of employe turnover intentions: An empirical study with Australian employees', Journal of Business Ethics 156, 759-774. https://doi.org/10.1007/s10551-017-3575-6

Heinen, M.M., Achterberg, T.V., Schwendimann, R., Zander, B., Matthews, A., Kózka, M. et al., 2013, 'Nurses' intention to leave their profession: A cross sectional observational study in 10 European countries', International Journal of Nursing Studies 50(2), 174-184. https://doi.org/10.1016/j.ijnurstu.2012.09.019

Hikido, A., 2017, 'Entrepreneurship in South African township tourism: The impact of interracial social capital', Ethnic and Racial Studies 41(14), 2580-2598. https://doi. org/10.1080/01419870.2017.1392026

Hlanyan, T.B. \& Aacheampong, O., 2017, 'Tourism entrepreneurship: The contours of challenges faced by female-owned B\&Bs and guesthouses in Mthatha, South Africa', African Journal of Hospitality, Tourism and Leisure 6(4), 1-17, viewed 15 December 2018, from https://www.ajhtl.com/uploads/7/1/6/3/7163688/article_50_
vol_6_4_2017.pdf.

Holston-okae, B., 2017, 'Employee turnover intentions in the hospitality industry', Masters' thesis, Walden University, MA.

Hsieh, Y.C \& Lin Y.H. 2010, 'Bed and breakfast operators' work and personal life balance: a cross-cultural comparison', International Journal of Hospitality Management 29(4), 576-581.

Hwang, J., Lee, J.J., Park, S., Chang, H. \& Kim, S.S., 2016, 'The impact of occupational stress on employee's turnover intention in the luxury hotel segment', International stress on employee's turnover intention in the luxury hotel segment', International
Journal of Hospitality and Tourism Administration 15(1), 60-77. https://doi.org/ Journal of Hospitality and Tourism
$10.1080 / 15256480.2014 .872898$

Ibrar, M., 2015, 'The influences of employee job satisfaction an organizational commitment on turnover intention', Arabian Journal of Business and Management Review 6(1), 169-172. http://doi.org/10.4172/2223-5833.1000169

Jang, J. \& Kandampull, J., 2018, 'Reducing employee turnover intention through servant leadership in the restaurant context: A mediation study of affective organizational commitment', International Journal of Hospitality \& Tourism Administration 19(2), 125-141. http://doi.org/10.1080/15256480.2017.1305310

Jang, J. \& George, R.T., 2012, 'Understanding the influence of polychronicity on job satisfaction and turnover intentions: A study of non-supervisory hotel employees', International Journal of Hospitality Management 31(2), 588-595. https://doi. org/10.1016/j.ijhm.2011.08.004

Johansson, A., 2016, The 7 biggest challenges that face small business owners in 2016 viewed 31 April 2018, from https://www.inc.com/anna-johansson/the-7-biggestchallenges-that-small-business-owners-face-in-2016.html.

Johnson, A.A., 1995, 'The business case for work-family programs', Journal of Accountancy $180(2), 53-57$.

Jung, H.S. \& Yoon, H.H., 2016, 'What does work meaning to hospitality employees? The effects of meaningful work on employees' organizational commitment: The mediating role of job engagement', International Journal of Hospitality Management 53, 59-68. https://doi.org/10.1016/j.ijhm.2015.12.004

Kampkotter, P., 2017, 'Performance appraisals and job satisfaction', The International Journal of Human Resource Management 28(5), 750-774. https://doi.org/10.1080/09585192.2015.1109538

Kang, H.J., Busser, J. \& Choi, H.M., 2018, 'Service climate: How does it affect turnover intention?' International Journal of Contemporary Hospitality Management 30(1), 76-94. https://doi.org/10.1108/IJCHM-04-2016-0185
Kanten, P., Kanten, S. \& Gurlek, M., 2015, 'The effects of organizational structures and learning organization on job embeddedness and individual adaptive performance', Procedia Economics and Finance 23, 1358-1366. http://doi.org/10.1016/S2212Procedia Economics

Katsikea, E., Theodosiou, M. \& Morgan, R., 2016, 'Why people quit: Explaining employee turnover intentions among export managers', International Business Review 24(3), 367-379. http://doi.org/10.1016/j.ibusrev.2014.08.009

Khaleefa, Q. \& Al-abdalaat, A., 2017, 'The impact of financial and moral dimensions of hotel on the staff turnover intention: A field study on five stars hotel in Aqaba special economic zone authority (ASEZA)', International Journal of Academic Research in Business and Social Sciences 6(12), 658-677. https://doi.org/10.6007/ Research in Business
IJARBSS/v6-i12/2527

Khan, S., Jehan, N., Shaheen, S. \& Ali, G., 2018, 'Effect of burnout on organizational citizenship behaviors: Mediating role of affective and continuance commitment' Abasyn Journal of Social Sciences 2, 1-13.

Kothari, C.R., 2004, Research methodology: Methods and techniques, New Age International Publishers, New Delhi.

Kim, I., Im, J. \& Hwang, J., 2015, 'The effects of mentoring on role stress, job attitude, and intention to quit in the hotel industry', International Journal of Hospitality Management 48, 68-82. https://doi.org/10.1016/j.ijhm.2015.04.006

Kim, J., Candido, C., Thomas, I. \& de Dear, R., 2016, 'Desk ownership in the workplace: The effect of non-territorial working on employee workplace satisfaction, perceived productivity and health', Building and Environment 103, 203-214. https://doi.org/10.1016/j.buildenv.2016.04.015

Kim, J.S., Song, H.J. \& Lee, C., 2016, 'Effects of corporate social responsibility and internal marketing on organizational commitment and turnover intentions', International Journal of Hospitality Management 55, 25-32. https://doi. org/10.1016/j.ijhm.2016.02.007

Lensen, B., 2016, 'The influence of hierarchy in organizations on employee turnover intentions', Master's thesis, Business Economics, Universiteit van Amsterdam.

Lee, J.S., Back, K.J. \& Chan, E.S., 2015, 'Quality of work life and job satisfaction among frontline hotel employees: A self-determination and need satisfaction theory approach', International Journal of Contemporary Hospitality Management 27(5), 768-789. https://doi.org/10.1108/IJCHM-11-2013-0530.

Li, P. \& Lu, H., 2014, 'Research on initiative turnover rate of the post-90s workforceTaking labor-intensive enterprises as an example', Journal of Human Resource and Sustainability Studies 2(1), 12-25. https://doi.org/10.4236/jhrss.2014.21002

Li, K. \& Malik, J., 2018, Implicit Maximum Likelihood Estimation, arXiv preprint arXiv:1809.09087: 1-21.

Lo, K. \& Lamm, F., 2015, 'Occupational stress in the hospitality industry - An employment relations perspective', New Zealand Journal of Employment Relations 30(1), 22-48.

Lu, L., Lu, A.C., Gursoy, D. \& Neale, N.R., 2016, 'Work engagement, job satisfaction, and turnover intentions: A comparison between supervisors and line-level employees', International Journal of Contemporary Hospitality Management 28(4), 737-761. http://doi.org/10.1108/IJCHM-07-2014-0360

Malhotra, N.K., Nunan, D. \& Birks, D.F., 2017, Marketing research: An applied approach, Pearson, London.

Markey, R., Ravenswood, K. \& Webber, D.J., 2015, 'Quality of work environment and quitting intention: A dilemma', New Zealand Journal of Employment Relations $40(1), 35-52$.

Mat-nor, A.N., Ahmad, Z., Khalid, S.A. \& Ibrahim, I.I., 2017, 'Factors affecting turnover intention among gen $\mathrm{y}$ in hotel industry', International Conference on Future Asian, Special Issue 12(1), 1-5.

Meyer, J.P. \& Allen, N.J., 1997, Commitment in the workplace: Theory, research, and application, Sage, Thousand Oaks, CA.

Mccoy, J.M. \& Evans, G.W., 2015, Physical work environment: Handbook of work stress, Sage, London.

Moon, J. \& Moon, S., 2004, The case for mixed methodology research: A review of literature and methods, viewed 20 August 2018, from http://www.emel.co.uk/ literature and methods, viewed
Mixed\%20methodology.pdf.

Munsor, S. \& Mohanna, D., 2018, 'Mediating role of job stress between work-family conflict, work-leisure conflict, and employees' perception of service quality in the hotel industry in France', Journal of Human Resources in Hospitality and Tourism 17(2), 154-174. https://doi.org/10.1080/15332845.2017.1340755

Namra, R. \& Tahira, M., 2017, 'Job stress, psychological capital and turnover intentions in employees of hospitality industry', Journal of Behavioural Sciences 27(2), 59-79.

Nankervis, A. \& Debrah, Y., 2015, 'Human resource management in hospitality: A comparative study', Tourism Management 16(7), 507-513. http://doi. org/10.5281/zenodo.1132547

Newnham, M.P., 2017, 'A comparison of the enactment and consequences of emotional labor between frontline hotel workers in two contrasting societal cultures', Journal of Human Resources in Hospitality and Tourism 16(2), 192-214. https://doi.org/10.1080/15332845.2016.1202729

Nykiel, R.A., 2007, Handbook of marketing research methodologies for hospitality and tourism, The Haworth Press, New York, NY.

Omar, K., Anuar, M.M., Majid, A.H.A. \& Johari, H., 2012, ‘Organizational commitment and intention to leave among nurses in Malaysian public hospitals', International Journal of Business and Social Science 3(16), 194-199.

Onyebu, C.M. \& Omotayo, O.A., 2017, 'Employee job satisfaction and organizational performance: An insight from selected hotels in Lagos Nigeria', Kuwait Chapter of Arabian Journal of Business and Management Review 33(5467), 1-12. http://doi. org/10.12816/0039071 
Palacios-marques, D., Guijarro, M. \& Carrilero, A., 2016, 'The use of customer-centric philosophy in hotels to improve customer loyalty', Journal of Business \& Industrial Marketing 31(3), 339-348. http://doi.org/10.1108/JBIM-05-2013-0110

Pallant, J., 2010, 'SPSS survival manual: A step by step guide to data analysis using the SPSS program', McGraw Hill, New York, NY.

Poghosyan, I., Liu, J., Shang, J. \& D’auno, T., 2017, 'Practice environments and job satisfaction and turnover intentions of nurse practitioners: Implications for primary care workforce capacity', Healthcare Management Review 42(2), 162-171. http://doi.org/10.1097/HMR.0000000000000094

Pohler, D. \& Schmidt, J.A., 2015, 'Does pay-for-performance strain the employment relationship? The effect of manager bonus eligibility on non-management employee turnover', Personnel Psychology 69(2), 395-429. https://doi. org/10.1111/peps.12106

Porter, L.W., Steers, R.M., Mowday, R.T. \& Boulian, P.V., 1974, 'Organisational commitment, job satisfaction, and turnover among psychiatric technicians', commitment, job satisfaction, and turnover among psychiatric technician
Journal of Applied Psychology 59, 603-609. https://doi.org/10.1037/h0037335

Qiu, H., Haobin Ye, B., Hung, K. \& York, Q.Y., 2015, 'Exploring antecedents of employee Research 11(1), 53-66. https//doi.org/10.1080/19388160.2014.90875

Rizwan, M., Arshad, M.Q., Arshad, H.M., Munir, H. \& Iqbal, F., 2014, 'Determinants of employees intention to leave: A study from Pakistan', International Journal of Human Resource Studies 4(3), 2-6. http://doi.org/10.5296/IJHRS.V4I3.5871

Robinson, R.N., Kralj, A., Solnet, D.J., Goh, E. \& Callan, V., 2016, 'Thinking job embeddedness not turnover: Towards a better understanding of frontline hote worker retention', International Journal of Hospitality Management 36(1) 101-109, viewed from 4 January 2019 http://hdl.handle.net/10072/64156

Russo, S.D., Mascia, D. \& Morandi, F., 2018, 'Individual perceptions of HR practices, HRM strength and appropriateness of care: A meso, multilevel approach', The International Journal of Human Resources Management 29(2), 286-310. https://doi.org/10.1080/09585192.2016.1165276

Sangaran, G. \& Jeetesh, K., 2015, 'The effects of job satisfaction towards employe turnover in the hotel industry: A case study of hotels in Kuala Lumpur city center',
Journal of Tourism and Hospitality 4(1), 1-5. http://doi.org/10.4172/21670269.1000142

Santero-sanchez, R., Segovia-perez, M., Castro-nunez, B., Figueroa-domecq, C. \& Talon-ballestero, P., 2015, 'Gender differences in the hospitality industry: A job quality index', Tourism Management 51(1), 234-246. http://doi.org/10.1016/j. tourman.2015.05.025

Santhanam, N., Kamalanabhan, T.J., Dyaram, L. \& Ziegler, H., 2015, 'Examining the moderating effects of organizational identification between human resource practices and employee turnover intentions in Indian hospitality industry', Global Science and Technology Forum Journal on Business Review 4(1), 11-19. http://doi. org/10.5176/2010-4804_4.1.349

Santhanam, N., Kamalanabhan, T.J., Dyaram, L. \& Ziegler, H., 2017, 'Impact of human resource management practices on employee turnover intentions: Moderating role of psychological contract breach', Journal of Indian Business Research 9(3), 212-228. https://doi.org/10.1108/JIBR-10-2016-0116
Sinha, S., 2017, 'Organisational structure and work-related attitude: Mediating role of psychological empowerment', Journal of Organisation and Human Behaviour 6(3), 46.

Steil, A.V., Floriani, E.D. \& Bello, J.S.A., 2019, 'Antecedents of intention to leave the organization: A systematic review', Social Psychology 29, 1-11, e2910. https://doi. org/10.1590/1982-4327e2910

Thomas, O.O., 2015, 'Effects of organizational structure on job satisfaction in the Nigerian financial sector: Empirical insight from selected banks in Lagos State Journal of social Development 5(1), 96-108. http://doi.org/10.12816/0032083

Treuren, G.J.M., \& Frankish, E., 2014, 'Pay dissatisfaction and intention to leave: The moderating role of personal care worker client embeddedness', Nonprofit Management and Leadership 25(1), 5-21. https://doi.org/10.1002/nml.21108

Tse, H.M., Huan, X. \& Lam, W., 2013, 'Why does transformational leadership matter for employee turnover? A multi-foci social exchange perspective', Leadership Quarterly 24(5), 763-776. https://doi.org/10.1016/j.leaqua.2013.07.005

Ushus, M. \& Johney, J., 2015, 'Impact of performance appraisal and work motivation on work performance of employee: With special reference to a multi-specialty hospital in Kerala', International Organization of Scientific Research Journal of Business and Management 17(6), 21-24. https://doi.org/10.9790/487X17622124

Valentina, B. \& Cvelbar, I.K., 2018, 'What really defines the performance in hote industry? Managers' perspective using Delphi method', Economic and Business Review 20(3), 375-394. https://doi.org/10.15458/85451.70

Van Schalkwyk, S., Du Toit, D., Bothma, A.S. \& Rothmann, S., 2010, 'Job insecurity, leadership empowerment behaviour, employee engagement and intention to leave in a petrochemical laboratory', SA Journal of Human Resource Management 8(1), 15-21. https://doi.org/10.4102/sajhrm.v8i1.234

Vaske, J.J., Beaman, J. \& Sponarski, C.C., 2017, 'Rethinking internal consistency in Cronbach alpha', Leisure Sciences 39(2), 163-173. https://doi.org/10.1080/01490 400.2015.1127189

Vitez, O. 2017, Centralized vs, decentralized organizational structure, viewed 25 March 2019, from https://smallbusiness.chron.com/centralized-vs-decentralizedorganizational-structure-2785.html.

Wang, Z., 2019, The principles of trading economics, Springer, Shanghai

Watson, G., 2010, Resistance to change: In the planning of change, Holt, Rinehart \& Watson, New York, NY.

Wijnmaalen, J., Heyse, L. \& Voordijk, H., 2016, 'Organisational commitment and turnover intentions in humanitarian organizations', International Journal of Human Resources Development and Management 16(1-2), 47-66. https://doi. org/10.1504/IJHRDM.2016.075372

Zhen, Y., Mansorzd \& Chong, C.W., 2019, 'Person-organization fit and employees' voluntary turnover with the effects of job satisfaction in hotel industry' Proceedings of the 2019 10th International Conference on e-business', Management and Economics, Beijing Guangxi Hotel Plaza, Beijing, China, July 15-17, 2019, PP. 61-64. 